\title{
NOTES
}

\section{Palladium(0)-catalyzed Synthesis of Unsaturated Polyethers from Bifunctional Vinyloxiranes and Bisphenol Analogues}

\author{
Toshio KoIzUmI, ${ }^{\dagger}$ Tadayoshi Akita, Hiroshi Nishino, and Takeshi Endo* \\ Department of Applied Chemistry, The National Defense Academy, Hashirimizu, Yokosuka 239-8686, Japan \\ *Department of Polymer Science and Engineering, Yamagata University, Yonezawa 992-8510, Japan
}

(Received March 29, 2004; Accepted May 15, 2004; Published August 15, 2004)

\begin{abstract}
KEY WORDS Palladium-catalyzed Polymerization / Vinyloxirane / Polyaddition / Bisphenol / Unsaturated Polymers / Polyethers / Hydroxyl Group /

[DOI 10.1295/polymj.36.647]
\end{abstract}

The $\operatorname{Pd}(0)$-catalyzed reaction of vinyloxiranes with carbon nucleophiles is a very useful method for synthesis of functionalized compounds. ${ }^{1,2}$ On the other hand, relatively little is known about the $\operatorname{Pd}(0)$-catalyzed reaction of vinyloxiranes with phenols because carbon-carbon bond formation reactions have received much attention in organic synthesis. ${ }^{3,4}$ We recently reported that the $\operatorname{Pd}(0)$-catalyzed polyaddition of bifunctional vinyloxiranes [1,4-bis(2-vinylepoxyethyl)benzene (1a) and 1,4-bis(1-methyl-2-vinylepoxyethyl)benzene (1b)] with oxygen nucleophiles such as hydroquinone and bisphenol A could lead to the formation of new unsaturated polyethers containing an allyl aryl ether moiety and pendant hydroxyl groups (Scheme 1). ${ }^{5}$ Unsaturated polymers are of importance for synthesizing crosslinked polymers, and polymers with hydroxyl groups are also significant in functional polymers such as polymeric reagents. ${ }^{6}$ Accordingly, the unsaturated polyethers obtained from 1 and oxygen nucleophiles are regarded as a new type of functional polymers. Generally, it is very difficult to synthesize unsaturated polymers with hydroxyl and various functional groups by conventional polymerization methods. ${ }^{7}$ From the viewpoint of the development of a versatile synthetic method for such polymers, we have reported that the $\operatorname{Pd}(0)$-catalyzed polyaddition of $\mathbf{1}$ and carbon nucleophiles is a very useful method for the synthesis of unsaturated poly- mers having hydroxyl and functional groups. ${ }^{8,9}$ Polymer synthesis via $\pi$-allylpalladium intermediates has recently attracted attention. Suzuki reported the $\operatorname{Pd}(0)$-catalyzed ring-opening polymerization of cyclic monomers such as vinylcyclopropanes. ${ }^{10}$ More recently, Nomura reported the $\mathrm{Pd}(0)$-catalyzed allylic substitution polymerization using allylic monomers and malonic esters, which offers a new method of $\mathrm{Csp}^{3}-\mathrm{Csp}^{3}$ bond-forming polymerization of the monomers. ${ }^{11,12}$ In this article, we report the $\operatorname{Pd}(0)$-catalyzed polyaddition of 1 and bisphenol analogues such as 4,4'-dihydroxydiphenyl ether and 4,4'-dihydroxybenzophenone for synthesizing unsaturated polyethers with functional groups in the main chain. The $\operatorname{Pd}(0)$-catalyzed polyaddition of $\mathbf{1}$ was examined by use of bisphenol analogues having an electron-donating or electron-withdrawing group. The $\mathrm{Pd}(0)$-catalyzed polyaddition of 1 and bisphenol analogues will be a more useful method for the synthesis of unsaturated polyethers bearing functional groups, if various bisphenol analogues can be used.

\section{EXPERIMENTAL}

\section{Measurement}

Fourier transfer infrared (FT-IR) spectra were obtained with a JASCO FT/IR-230 spectrometer. ${ }^{1} \mathrm{H}$ and ${ }^{13} \mathrm{C}$ NMR spectra were measured on a Bruker-

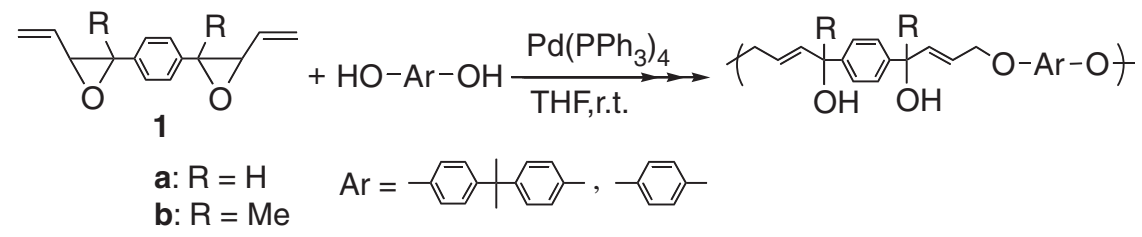

Scheme 1. Pd(0)-catalyzed polyaddition of vinyloxiranes $\mathbf{1}$ and oxygen nucleophiles.

\footnotetext{
${ }^{\dagger}$ To whom correspondence should be addressed (E-mail: tkoizumi@nda.ac.jp).
} 
DMX 500 or JEOL JNM-AL300 using dimethyl sulfoxide- $d_{6}\left(\mathrm{DMSO}-d_{6}\right)$ as a solvent and $\mathrm{Me}_{4} \mathrm{Si}$ as an internal standard. Gel permeation chromatography (GPC) measurements were performed on a TOSOH HLC8220 GPC system equipped with three columns (TSK-GEL SUPER HM-M, H3000, and H2000) using tetrahydrofuran (THF) as an eluent at $40^{\circ} \mathrm{C}$. Calibration curves for GPC were obtained using standard polystyrene samples.

\section{Materials}

Extra-pure grade reagents were used without further purification. Bifunctional vinyloxiranes 1 were prepared by the method reported in our previous paper. ${ }^{8}$ THF used as the solvent for the $\operatorname{Pd}(0)$-catalyzed polyaddition was distilled from sodium/benzophenone ketyl under nitrogen prior to use.

$P d(0)$-catalyzed Polyaddition of Bifunctional Vinyloxiranes (1) with Bisphenol Analogues: A Typical Procedure. To a yellow solution of $\mathrm{Pd}\left(\mathrm{PPh}_{3}\right)_{4}$ $(0.058 \mathrm{~g}, 0.05 \mathrm{mmol})$ in THF $(2 \mathrm{~mL}) 4,4^{\prime}$-dihydroxydiphenyl ether $(\mathbf{2 c} ; 0.202 \mathrm{~g}, 1.0 \mathrm{mmol})$ was added. To this mixture a solution of bifunctional vinyloxirane 1b $(0.242 \mathrm{~g}, 1.0 \mathrm{mmol})$ in THF $(1 \mathrm{~mL})$ was added. The mixture was stirred at room temperature under an Ar atmosphere. After $24 \mathrm{~h}$, the reaction mixture was poured into toluene $(100 \mathrm{~mL})$ to precipitate the polymer (run 1 in Table II). The resulting polymer was filtered off, washed with toluene, and dried in $v a$ сио $(0.352 \mathrm{~g}, 79 \%)$ giving polymer 3bc: IR $(\mathrm{KBr})$ : 3427,3043 , 2976, 2925, 2866, 1496, 1207, 1012, $833 \mathrm{~cm}^{-1} .{ }^{1} \mathrm{H}$ NMR $\left(300 \mathrm{MHz}, \mathrm{DMSO}-d_{6}\right): \delta 1.53$ $\left(\mathrm{CH}_{3}, \mathrm{~s}, 6 \mathrm{H}\right), 4.50\left(-\mathrm{CH}_{2}-, \mathrm{d}, J=5.1 \mathrm{~Hz}, 4 \mathrm{H}\right), 5.27$ $(\mathrm{OH}, \mathrm{s}, 2 \mathrm{H}), 5.79-5.88\left(-\mathrm{CH}=\mathrm{CHCH}_{2}-, \mathrm{m}, 2 \mathrm{H}\right)$, $6.09(-\mathrm{CCH}=\mathrm{CH}-, \mathrm{d}, J=15.3 \mathrm{~Hz}, 2 \mathrm{H}), 6.86-6.94$ $(\mathrm{ArH}, \quad \mathrm{m}, \quad 8 \mathrm{H}), \quad 7.36 \quad(\mathrm{ArH}, \quad \mathrm{s}, \quad 4 \mathrm{H}) .{ }^{13} \mathrm{C} \mathrm{NMR}$ $\left(75 \mathrm{MHz}\right.$, DMSO- $\left.d_{6}\right): \delta 29.5,68.1,72.4,115.8$, $119.2,121.3,124.5,141.5,145.7,150.9,154.0$.

Polyester 3bd: IR (KBr): 3415, 3030, 2974, 2925 , 2864, 1591, 1489, 1236, 1009, $827 \mathrm{~cm}^{-1} .{ }^{1} \mathrm{H}$ NMR $\left(300 \mathrm{MHz}, \mathrm{DMSO}-d_{6}\right): \delta 1.52\left(\mathrm{CH}_{3}, \mathrm{~s}, 6 \mathrm{H}\right), 4.53$ $\left(-\mathrm{CH}_{2}-, \mathrm{d}, J=5.4 \mathrm{~Hz}, 4 \mathrm{H}\right), 5.28(\mathrm{OH}, \mathrm{s}, 2 \mathrm{H}), 5.79-$ $5.88\left(-\mathrm{CH}=\mathrm{CHCH}_{2}-, \mathrm{m}, 2 \mathrm{H}\right), 6.10(-\mathrm{CCH}=\mathrm{CH}-$, $\mathrm{d}, J=15.3 \mathrm{~Hz}, 2 \mathrm{H}), 6.92(\mathrm{ArH}, \mathrm{d}, J=8.4 \mathrm{~Hz}, 4 \mathrm{H})$, $7.23(\mathrm{ArH}, \mathrm{d}, J=8.4,4 \mathrm{H}), 7.36(\mathrm{ArH}, \mathrm{s}, 4 \mathrm{H})$. ${ }^{13} \mathrm{C}$ NMR $\left(75 \mathrm{MHz}\right.$, DMSO- $\left.d_{6}\right): \delta 29.5,67.9,72.4$, 115.7, 121.0, 124.5, 126.4, 132.4, 141.7, 145.7, 157.7.

Polyester 3be: IR (KBr): 3429, 3041, 2974, 2927, 2866, 1599, 1506, 1252, 1165, $845 \mathrm{~cm}^{-1} .{ }^{1} \mathrm{H}$ NMR $\left(300 \mathrm{MHz}, \mathrm{DMSO}-d_{6}\right): \delta 1.49\left(\mathrm{CH}_{3}, \mathrm{~s}, 6 \mathrm{H}\right), 4.61$ $\left(\mathrm{CH}_{2}\right.$, br s, $\left.4 \mathrm{H}\right), 5.80-5.85\left(-\mathrm{CH}=\mathrm{CHCH}_{2}-, \mathrm{m}, 2 \mathrm{H}\right)$, $6.10(-\mathrm{CCH}=\mathrm{CH}-, \mathrm{d}, J=15.3 \mathrm{~Hz}, 2 \mathrm{H}), 7.02(\mathrm{ArH}$, d, $J=8.1 \mathrm{MHz}, 4 \mathrm{H}), 7.33(\mathrm{ArH}, \mathrm{s}, 4 \mathrm{H}), 7.64(\mathrm{ArH}$, $\mathrm{d}, J=8.4 \mathrm{MHz}, 4 \mathrm{H}) .{ }^{13} \mathrm{C}$ NMR $(75 \mathrm{MHz}, \mathrm{DMSO}-$ $\left.d_{6}\right): \delta 29.5,68.0,72.4,114.3,120.7,124.6,130.0$,
131.6, 142.1, 145.7, 161.5, 193.0.

Polyester 3bf: IR (KBr): 3446, 2976, 2927, 2870, $1591,1495,1255,1147,1107,980,837 \mathrm{~cm}^{-1}$. ${ }^{1} \mathrm{H}$ NMR $\left(300 \mathrm{MHz}\right.$, DMSO- $\left.d_{6}\right): \delta 1.51\left(\mathrm{CH}_{3}, \mathrm{~s}\right.$, $6 \mathrm{H}), 4.63\left(-\mathrm{CH}_{2}-, \mathrm{d}, J=4.8 \mathrm{~Hz}, 4 \mathrm{H}\right), 5.79-5.87$ $\left(-\mathrm{CH}=\mathrm{CHCH}_{2}-, \mathrm{m}, 2 \mathrm{H}\right), 6.12(-\mathrm{CCH}=\mathrm{CH}-, \mathrm{d}, J=$ $15.3 \mathrm{~Hz}, 2 \mathrm{H}), 7.10(\mathrm{ArH}, \mathrm{d}, J=7.5 \mathrm{MHz}, 4 \mathrm{H}), 7.35$ $(\mathrm{ArH}, \mathrm{s}, 4 \mathrm{H}), 7.82(\mathrm{ArH}, \mathrm{d}, J=7.2 \mathrm{~Hz}, 4 \mathrm{H}) .{ }^{13} \mathrm{C}$ NMR $\left(75 \mathrm{MHz}\right.$, DMSO- $\left.d_{6}\right): \delta \quad 29.4,68.2,72.4$, 115.4, 120.3, 124.5, 129.1, 133.4, 142.3, 145.6, 161.8.

Polyester 3ac: IR (KBr): 3383, 3045, 2974, 2870, 1498, 1207, 1057, 1011, $831 \mathrm{~cm}^{-1} .{ }^{1} \mathrm{H}$ NMR $(300$ MHz, DMSO- $\left.d_{6}\right): \delta 4.50\left(\mathrm{CH}_{2}, \mathrm{~d}, J=3.9 \mathrm{~Hz}, 4 \mathrm{H}\right)$, $5.12(\mathrm{CH}, \mathrm{s}, 2 \mathrm{H}), 5.46(\mathrm{OH}, \mathrm{d}, J=4.5 \mathrm{~Hz}, 2 \mathrm{H})$, 5.84-6.00 $(-\mathrm{CH}=\mathrm{CH}-, \mathrm{m}, 4 \mathrm{H}), 6.82-6.93(\mathrm{ArH}, \mathrm{m}$, $8 \mathrm{H}), 7.33$ (ArH, s, 4H). ${ }^{13} \mathrm{C}$ NMR $(75 \mathrm{MHz}$, DMSO$\left.d_{6}\right): \delta 67.9,72.2,115.8,119.2,124.0,125.8,137.1$, 142.8, 150.9, 154.0.

Polyester 3ad: IR (KBr): 3381, 2972, 2870, 1591, 1489, 1236, 1061, 1007, $827 \mathrm{~cm}^{-1} .{ }^{1} \mathrm{H}$ NMR $\left(500 \mathrm{MHz}, \mathrm{DMSO}-d_{6}\right): \delta 4.53\left(\mathrm{CH}_{2}, \mathrm{~d}, J=4.0 \mathrm{~Hz}\right.$, $4 \mathrm{H}), 5.18(\mathrm{CH}, \mathrm{s}, 2 \mathrm{H}), 5.57(\mathrm{OH}, \mathrm{s}, 2 \mathrm{H}), 5.87-5.98$ $(-\mathrm{CH}=\mathrm{CH}-, \mathrm{m}, 4 \mathrm{H}), 6.93(\mathrm{ArH}, \mathrm{d}, J=8.1 \mathrm{MHz}$, $4 \mathrm{H}), 7.26(\mathrm{ArH}, \mathrm{d}, J=8.6 \mathrm{MHz}, 4 \mathrm{H}), 7.28(\mathrm{ArH}, \mathrm{s}$, $4 \mathrm{H}) .{ }^{13} \mathrm{C}$ NMR $\left(125 \mathrm{MHz}, \mathrm{DMSO}-d_{6}\right): \delta 68.0,72.6$, 116.9, 124.0, 126.4, 126.8, 132.9, 137.9, 143.2, 158.1.

Polyester 3ae: IR (KBr): 3400, 3037, 2868, 1599, 1506, 1248, 1165, 1001, 928, $847 \mathrm{~cm}^{-1}$. ${ }^{1} \mathrm{H}$ NMR $\left(500 \mathrm{MHz}, \mathrm{DMSO}-d_{6}\right): \delta 4.66\left(\mathrm{CH}_{2}\right.$, br s, $\left.4 \mathrm{H}\right), 5.16$ $(\mathrm{CH}, \mathrm{d}, J=5.2 \mathrm{~Hz}, 2 \mathrm{H}), 5.93-6.04(-\mathrm{CH}=\mathrm{CH}-, \mathrm{m}$, 4H), 7.08 (ArH, d, $J=8.5 \mathrm{MHz}, 4 \mathrm{H}), 7.32(\mathrm{ArH}, \mathrm{s}$, $4 \mathrm{H}), 7.70(\mathrm{ArH}, \mathrm{d}, J=8.5 \mathrm{MHz}, 4 \mathrm{H})$.

Polyester 3af: IR (KBr): 3429, 3103, 3059, 2918, $1591,1495,1294,1255,1147,1105,978,833 \mathrm{~cm}^{-1}$. ${ }^{1} \mathrm{H}$ NMR $\left(500 \mathrm{MHz}\right.$, DMSO- $\left.d_{6}\right): \delta 4.62\left(\mathrm{CH}_{2}, \mathrm{br} \mathrm{s}\right.$, $4 \mathrm{H}), \quad 5.19(\mathrm{CH}, \quad \mathrm{d}, \quad J=5.2 \mathrm{~Hz}, 2 \mathrm{H}), \quad 5.80-5.85$ $(-\mathrm{CH}=\mathrm{CH}-, \mathrm{m}, 4 \mathrm{H}), 7.09(\mathrm{ArH}, \mathrm{d}, J=8.1 \mathrm{MHz}$, $4 \mathrm{H}), 7.28(\mathrm{ArH}, \mathrm{s}, 4 \mathrm{H}), 7.84(\mathrm{ArH}, \mathrm{d}, J=8.6 \mathrm{MHz}$, $4 \mathrm{H})$.

\section{RESULTS AND DISCUSSION}

In our previous paper, we reported that the $\mathrm{Pd}(0)$ catalyzed polyaddition of bifunctional vinyloxirane 1a with hydroquinone and bisphenol A could afford the corresponding unsaturated polyethers with hydroxyl groups when $\mathrm{Pd}\left(\mathrm{PPh}_{3}\right)_{4}$ was used. ${ }^{5} \mathrm{Pd}_{2}(\mathrm{dba})_{3}$. $\mathrm{CHCl}_{3}$ /1,2-bis(diphenylphosphino)ethane (dppe) as a catalyst (where dba is dibenzylideneacetone) was not effective, and the yields and number-average molecular weights $\left(M_{\mathrm{n}}\right)$ of the obtained polyethers were lower than those of the polyethers obtained by polymerization using $\operatorname{Pd}\left(\mathrm{PPh}_{3}\right)_{4}$. Therefore, the $\operatorname{Pd}(0)$ catalyzed polyaddition of $\mathbf{1 a}$ and bisphenol analogues was examined in THF under an Ar atmosphere in the 
Table I. $\operatorname{Pd}(0)$-catalyzed polyaddition of $\mathbf{1 a}$ and bisphenol analogues $(\mathbf{2} \mathbf{c}-\mathbf{f})^{\mathrm{a}}$

(n)

${ }^{\mathrm{a} C}$ Conditions: 1a $(1.0 \mathrm{mmol}), 2(1.0 \mathrm{mmol}), \mathrm{Pd}\left(\mathrm{PPh}_{3}\right)_{4}\left(5 \mathrm{~mol} \%\right.$ for 1a), THF $(3 \mathrm{~mL}) .{ }^{\mathrm{b}}$ Insoluble in toluene. ${ }^{\mathrm{c}}$ Estimated by GPC (based on PSt).

presence of $\mathrm{Pd}\left(\mathrm{PPh}_{3}\right)_{4}$. The formed polymers were isolated by the pouring of the reaction mixture into toluene. The results are summarized in Table I. 4,4'Dihydroxydiphenyl ether (2c), which has an ether linkage having an electron-donating function, afforded the desired unsaturated polyether (3ac) in a $95 \%$ yield by polymerization at room temperature for $24 \mathrm{~h}\left(M_{\mathrm{n}}=2200\right.$; run 1$)$. The $\operatorname{Pd}(0)$-catalyzed polyaddition of $\mathbf{1 a}$ and 4,4'-dihydroxydiphenyl sulfide (2d) also gave the corresponding polyether (3ad) with sulfide bonds in the main chain in a good yield $\left(M_{\mathrm{n}}=2500\right.$; run 2). The structures of $\mathbf{3 a c}$ and $\mathbf{3 a d}$ were confirmed by NMR and IR. Signals based on the methylene protons of 3ac and 3ad appeared at 4.50 and $4.53 \mathrm{ppm}$, respectively. Signals due to the methine proton $[-\mathrm{CH}(\mathrm{OH})-]$ of the polymers were also observed at 5.12 and $5.18 \mathrm{ppm}$, respectively. In the IR spectra, absorptions based on the hydroxyl groups of 3ac and 3ad were observed around 3383 and $3381 \mathrm{~cm}^{-1}$, respectively. These spectral data revealed that the polyaddition of $\mathbf{1 a}$ using $\mathbf{2 c}$ and $\mathbf{2 d}$ proceeded successfully similar to that of 1a using hydroquinone and bisphenol A. Next, 4,4'-dihydroxybenzophenone (2e) and 4,4'-dihydroxydiphenyl sulfone (2f), which have an electron-withdrawing group, were examined as oxygen nucleophiles. The $\operatorname{Pd}(0)$-catalyzed polyaddition of 1a and $2 \mathbf{e}$ was conducted at room temperature for $24 \mathrm{~h}$, and a toluene-insoluble product was obtained. However, the $M_{\mathrm{n}}$ value of the product 3ae was very low $\left(M_{\mathrm{n}}=680\right.$; run 3$)$. The polyaddition of 1a and $2 \mathbf{f}$ also gave a toluene-insoluble product 3af, but the yield and $M_{\mathrm{n}}$ value were low $\left(35 \%, M_{\mathrm{n}}=910\right.$; run 4). 1a was completely consumed in this case. 3af was not obtained by polymerization of $\mathbf{1 a}$ and $\mathbf{2 f}$

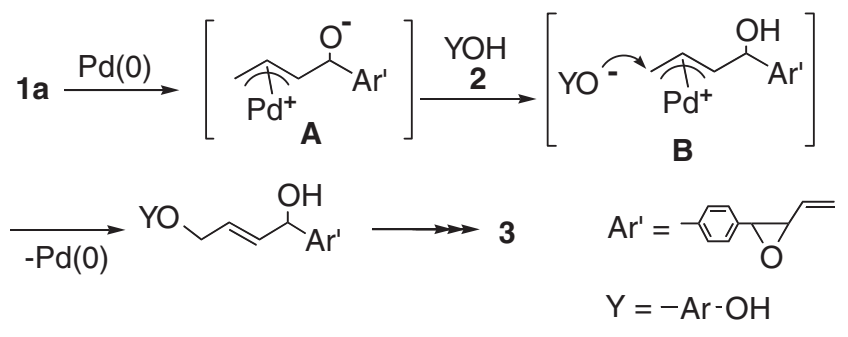

Scheme 2. Polymerization mechanism.

for $6 \mathrm{~h}$, and the presence of 1a was ascertained by NMR. These results indicate that $\mathbf{2 e}$ and $\mathbf{2 f}$ are not suitable substrates for the polyaddition with 1a. The reason is not clear at this stage. $2 \mathbf{e}$ and $\mathbf{2} \mathbf{f}$ have a carbonyl and sulfonyl groups as an electron-withdrawing group, respectively. Therefore, the phenoxide ions generated by hydrogen abstraction of the $\pi$-allylpalladium intermediate (A) seem not to have sufficient nucleophilicity. It can therefore be presumed that nucleophilic attack of the phenoxide ions generated from $2 \mathbf{e}$ and $\mathbf{2 f}$ onto intermediate $\mathbf{B}$ were slow (Scheme 2). In the ${ }^{1} \mathrm{H}$ NMR spectra of the obtained oligomeric products, the methylene and methine protons due to $\mathbf{3 a e}$ and 3af were observed, and signals based on the bifunctional vinyloxirane 1a disappeared completely. The IR spectra of 3ae and 3af showed the characteristic absorptions based on the hydroxyl groups. These spectral data supported the structures of 3ae and 3af.

Second, we examined the $\operatorname{Pd}(0)$-catalyzed polyaddition between bisphenol analogues $2 \mathbf{c}-\mathbf{f}$ and bifunctional vinyloxirane $\mathbf{1 b}$. In the polyaddition of $\mathbf{1 b}$ and bisphenol $\mathrm{A}$, the desired unsaturated polyether could be obtained by polymerization using $\mathrm{Pd}_{2}(\mathrm{dba})_{3}$. $\mathrm{CHCl}_{3} /$ dppe as well as $\mathrm{Pd}\left(\mathrm{PPh}_{3}\right)_{4} .^{5}$ Therefore, 
Table II. Pd(0)-catalyzed polyaddition of $\mathbf{1 b}$ and bisphenol analogues $\mathbf{2} \mathbf{c}-\mathbf{f}^{\text {a }}$

\begin{tabular}{|c|c|c|c|c|c|}
\hline & $1 \mathrm{O}$ & $\begin{array}{l}\mathrm{HO}-\mathrm{Ar}-\mathrm{OH} \\
2\end{array}$ & & $\begin{array}{l}\mathrm{OH} \\
3 \mathrm{bc}\end{array}$ & ot \\
\hline Run & $\begin{array}{c}2 \\
(\mathrm{Ar}=)\end{array}$ & $\operatorname{Pd}(0)$ & $\begin{array}{c}\text { Yield }^{\mathrm{b}} \\
(\%)\end{array}$ & $M_{\mathrm{n}}{ }^{\mathrm{c}}$ & $M_{\mathrm{w}} / M_{\mathrm{n}}^{\mathrm{c}}$ \\
\hline 1 & c & $\mathrm{Pd}\left(\mathrm{PPh}_{3}\right)_{4}$ & 79 & 10600 & 2.88 \\
\hline 2 & c & $\mathrm{Pd}_{2}(\mathrm{dba})_{3} \cdot \mathrm{CH}_{3} \mathrm{Cl} / \mathrm{dppe}$ & 98 & 13800 & 3.00 \\
\hline 3 & d & $\mathrm{Pd}\left(\mathrm{PPh}_{3}\right)_{4}$ & 76 & 9600 & 2.35 \\
\hline 4 & d & $\mathrm{Pd}_{2}(\mathrm{dba})_{3} \cdot \mathrm{CH}_{3} \mathrm{Cl} / \mathrm{dppe}$ & 98 & 6300 & 3.21 \\
\hline 5 & $\mathbf{e}$ & $\mathrm{Pd}\left(\mathrm{PPh}_{3}\right)_{4}$ & 100 & 2500 & 2.06 \\
\hline 6 & $\mathbf{e}$ & $\mathrm{Pd}_{2}(\mathrm{dba})_{3} \cdot \mathrm{CH}_{3} \mathrm{Cl} / \mathrm{dppe}$ & 0 & & \\
\hline 7 & $\mathbf{f}$ & $\mathrm{Pd}\left(\mathrm{PPh}_{3}\right)_{4}$ & 53 & 1200 & 2.10 \\
\hline 8 & $\mathbf{f}$ & $\mathrm{Pd}_{2}(\mathrm{dba})_{3} \cdot \mathrm{CH}_{3} \mathrm{Cl} / \mathrm{dppe}$ & 0 & & \\
\hline
\end{tabular}

${ }^{\mathrm{a} C}$ Conditions: 1b $(1.0 \mathrm{mmol}), \mathbf{2}(1.0 \mathrm{mmol}), \mathrm{Pd}(0)(5 \mathrm{~mol} \%$ for $\mathbf{1 b})$, THF $(3 \mathrm{~mL}) .{ }^{\mathrm{b}}$ Insoluble in toluene. ${ }^{\mathrm{c}}$ Estimated by GPC (based on PSt).

$\mathrm{Pd}\left(\mathrm{PPh}_{3}\right)_{4}$ and $\mathrm{Pd}_{2}(\mathrm{dba})_{3} \cdot \mathrm{CHCl}_{3} /$ dppe were employed as catalysts. The polyaddition of $\mathbf{1 b}$ and $\mathbf{2 c - f}$ was carried out in THF at room temperature for $24 \mathrm{~h}$ in the presence of a $\mathrm{Pd}(0)$ catalyst $(5 \mathrm{~mol} \%$ for $\mathbf{1 b})$. Table II shows the results. The yields and $M_{\mathrm{n}}$ values of the obtained polyethers (3bc-f) were largely affected by the kinds of bisphenol analogues employed. Unsaturated polyethers with high $M_{\mathrm{n}}$ values were obtained by polymerization using $\mathbf{2 c}$ and $\mathbf{2 d}$ as oxygen nucleophiles. The $\mathrm{Pd}(0)$-catalyzed polyaddition of 1b and 2c was carried out in the presence of $\mathrm{Pd}\left(\mathrm{PPh}_{3}\right)_{4}$ and afforded the corresponding polyether (3bc) in a $79 \%$ yield $\left(M_{\mathrm{n}}=10600\right.$; run 1). The yield and $M_{\mathrm{n}}$ value of polyether $\mathbf{3 b c}$ were higher when dppe was used as a ligand instead of $\mathrm{PPh}_{3}\left(98 \%, M_{\mathrm{n}}=\right.$ 13800; run 2). The similar tendency was observed in the $\operatorname{Pd}(0)$-catalyzed polyaddition of $\mathbf{1 b}$ and hydroquinone. ${ }^{5}$ The polyaddition of $\mathbf{1 b}$ with $\mathbf{2 d}$ was conducted by use of $\mathrm{Pd}\left(\mathrm{PPh}_{3}\right)_{4}$ and gave the desired polyether (3bd) with a high $M_{\mathrm{n}}$ value $\left(M_{\mathrm{n}}=9600\right.$; run 3$)$. When dppe was employed as a ligand, however, the $M_{\mathrm{n}}$ value of $3 \mathbf{b d}$ deceased $\left(M_{\mathrm{n}}=6300\right.$; run 4$)$, in contrast to the polyaddition $\mathbf{1 b}$ and $\mathbf{2 c}$. The structures of $\mathbf{3 b c}$ and 3bd were confirmed based on the NMR and IR spectral data (see the Experimental section). The stereochemistries were $E$ configurations; both the $J$ values of $3 \mathbf{b c}$ and $\mathbf{3 b d}$ were $15.3 \mathrm{~Hz}$.

In the polyaddition of $\mathbf{1 b}$ with $\mathbf{2 c}$ and $\mathbf{2 d}$, the $M_{\mathrm{n}}$ values of the obtained polyethers $\mathbf{3 b c}$ and $\mathbf{3 b d}$ were much higher than those of polyethers 3ac and 3ad obtained from 1a. The main reason why 1a gave polyethers with lower $M_{\mathrm{n}}$ values seems to be the occurrence of $\beta$-hydrogen elimination as a termination because the $\pi$-allylpalladium intermediate generated by the oxidative addition of $\operatorname{Pd}(0)$ to 1 a has a $\beta$-hydrogen atom at the benzylic position. ${ }^{8,12,13}$
The $\operatorname{Pd}(0)$-catalyzed polyaddition of $\mathbf{1 b}$ was next examined by use of $\mathbf{2 e}$ and $\mathbf{2 f}$, which have a carbonyl and sulfonyl groups as an electron-withdrawing group, respectively. The corresponding polyethers were not obtained by polymerization using $\mathrm{Pd}_{2}(\mathrm{dba})_{3} \cdot \mathrm{CHCl}_{3} /$ dppe as a catalyst, and the starting vinyloxirane $\mathbf{1 b}$ was recovered (runs 6 and 8). The polyaddition of $\mathbf{1 b}$ and $\mathbf{2 e}$ in the presence of $\mathrm{Pd}\left(\mathrm{PPh}_{3}\right)_{4}$ produced the expected polyether (3be), the $M_{\mathrm{n}}$ value of which was not high $\left(M_{\mathrm{n}}=2500\right.$; run 5). The $M_{\mathrm{n}}$ value of the polyether (3bf) obtained from $\mathbf{1 b}$ and $\mathbf{2 f}$ was lower than that of polyether $3 \mathbf{b e}$ (run 7). The low $M_{\mathrm{n}}$ values of $3 \mathbf{b e}$ and $\mathbf{3 b f}$ are probably due to slow nucleophilic attack of the phenoxide ions generated from $2 \mathbf{e}$ and $\mathbf{2 f}$ onto the $\pi$-allylpalladium intermediate generated from $\mathbf{1 b}$, similar to the polyaddition of $1 \mathbf{a}$ with $\mathbf{2 e}$ and $\mathbf{2 f}$. From these results using $\mathbf{1 b}$ and $\mathbf{2 c}-\mathbf{f}$, the $\operatorname{Pd}(0)$-catalyzed polyaddition was found to be largely affected by the kinds of bisphenol analogues employed; the $M_{\mathrm{n}}$ values of the obtained polyethers decreased in the following order: 3bc $>$ 3bd $>$ 3be $>$ 3bf.

\section{CONCLUSIONS}

We found that the $\operatorname{Pd}(0)$-catalyzed polyaddition of 1b and bisphenol analogues 2c and 2d, which have an electron-donating group, afforded the corresponding unsaturated polyethers $3 \mathbf{b c}$ and $\mathbf{3 b d}$ with high $M_{\mathrm{n}}$ values. On the other hand, when $\mathbf{2 e}$ and $\mathbf{2 f}$, which have an electron-withdrawing group, were used, the $M_{\mathrm{n}}$ values of the obtained polymers $3 \mathrm{be}$ and $\mathbf{3 b f}$ were very low. In the polyaddition using $\mathbf{2 c}$ and $\mathbf{2 d}$, the $M_{\mathrm{n}}$ values of $\mathbf{3 b c}$ and $\mathbf{3 b d}$ were much higher than those of the polyethers 3ac and 3ad obtained by polymerization with 1a. Therefore, the combination of bifunc- 
tional vinyloxirane $\mathbf{1 b}$ and bisphenol analogues with an electron-donating group was found to be a better way for the synthesis of unsaturated polyethers with high $M_{\mathrm{n}}$ values.

\section{REFERENCES}

1. J. Tsuji, H. Kataoka, and Y. Kobayashi, Tetrahedron Lett., 22, 2575 (1981).

2. B. M. Trost and G. A. Molander, J. Am. Chem. Soc., 103, 5969 (1981).

3. R. K. Boeckman, Jr., J. R. Tagat, and B. H. Johnston, Heterocycles, 35, 33 (1987).

4. D. R. Deardorff, D. C. Myles, and K. D. MacFerrin, Tetrahedron Lett., 26, 5615 (1985).
5. T. Koizumi, T. Imai, and T. Endo, J. Polym. Sci., Part A: Polym. Chem., 41, 476 (2003).

6. A. Akelah and D. C. Sherrington, Chem. Rev., 41, 557 (1981).

7. R. Nomura and T. Endo, Macromolecules, 27, 1286 (1994).

8. T. Koizumi, J. Sakamoto, Y. Gondo, and T. Endo, Macromolecules, 35, 2898 (2002).

9. T. Koizumi, J. Sakamoto, Y. Gondo, and T. Endo, J. Polym. Sci., Part A: Polym. Chem., 40, 2487 (2002).

10. M. Suzuki, J. Synth. Org. Chem., Jpn., 51, 141 (1993).

11. N. Nomura, K. Tsurugi, and M. Okada, J. Am. Chem. Soc., 121, 7268 (1999).

12. N. Nomura, N. Yoshida, K. Tsurugi, and K. Aoi, Macromolecules, 36, 3007 (2003), and references cited therein.

13. M. Suzuki, Y. Oda, and R. Noyori, J. Am. Chem. Soc., 101, 1623 (1979). 